\title{
Relationships between the Usage of ICT, Attitudes, Behavior and Interest towards Achievement in Chemistry among Form Four Students
}

\author{
Md. Yusoff Daud, Mohd Jasmy Abd Rahman, Rosyafinah Mohamad \\ Centre of Innovation in Teaching and Learning, Faculty of Education, Universiti Kebangsaan Malaysia, Bangi, Malaysia \\ Email: mdyusoffdaud@ukm.edu.my
}

How to cite this paper: Daud, Md. Y., Rahman, M. J. A., \& Mohamad, R. (2019). Relationships between the Usage of ICT, Attitudes, Behavior and Interest towards Achievement in Chemistry among Form Four Students. Creative Education, 10, 2574-2583. https://doi.org/10.4236/ce.2019.1012185

Received: October 16, 2019

Accepted: November 24, 2019

Published: November 27, 2019

Copyright $\odot 2019$ by author(s) and Scientific Research Publishing Inc. This work is licensed under the Creative Commons Attribution International License (CC BY 4.0).

http://creativecommons.org/licenses/by/4.0/ (c) (i) Open Access

\begin{abstract}
The study is to examine the relationship between the usage of ICT, attitude, behavior, and interest towards the achievement in chemistry among form four students. The study would provide understanding of some of the learners' intrinsic factor as a result of their achievement in helping the learners to develop positive attitudes, which is a recipe for better learning and performance in the subject. A descriptive survey design is due to the nature of the study. The study involved 78 pupils form four from secondary schools in county of Selangor and the target population was the form four students who were about to sit for their SPM examinations. Purposive and random samplings were used in selecting the schools and the students with the use of questionnaires as a method of data collection. The questionnaires were designed to elaborate some of the students' attitude, behavior and interest regarding the chemistry subject. The data was collected and analyze with the use of statistical package for social sciences (SPSS). Differential and inferential statistic was used to analyze frequencies and percentages and Spearman's Rho correlation. The study found out that most students had a positive attitude towards chemistry. The findings also show that attitude, behavior and interest, show a significance relationship to achievement in chemistry. Whereas, the usage of ICT shows a weak relationship, affected their level of integrating which leads to low applications. The study recommends the use of varied instructional strategies by the teachers, which promote discovery and elicit learner interest. The students should be encouraged to apply the taught knowledge and skills through $21^{\text {st }}$ approach or learning, therefore, a need for stakeholder in education to offer and build on experiences and opportunities to every student to engage fully in whatever platform to acquire knowledge and skills.
\end{abstract}




\section{Keywords}

Relationship, Attitude, Behavior, Interest, Usage of ICT and Achievement

\section{Introduction}

In the 21st century, the rapid development of human civilization has resulted in the explosion of knowledge, the sophistication of science and technology and the needs of expertise in various fields of work. To provide the community with the development of science and technology needs a comprehensive program to educate people from primary schools throughout our nation. Education is a major contributor to the development of our social and economic capital. It inspires creativity and fosters innovation; provides our youth with the necessary skills to be able to compete in the modern labor market; and is a key driver of growth in the economy (MOE, 2013). Malaysia's vision to become a developed nation by the year 2020 has placed science and technology as a key important subject. This is especially that science and technology are often perceived as fundamental forces underlying growing of economic, development and technology. Various causal factors have been raised by experts in the field of education to explain the situation and problem of learning. Among these factors is lower achievement, lacking of basic skills, interests, attitudes, motivations, integration of ICT, facilities so on and so for. On the other hand, the rapid and continuing implementation of new information and communication technologies (ICT) in the education system raises expectations in terms of contribution and improvement of the quality of education (Muhamad Naqiuddin Hashim et al., 2019; Simin \& Ibrahim, 2015).

\subsection{Problems Statements}

In most schools or in the classroom, the multiple learning style has long been introduced. However, pupils involved in learning are still less implementation of the variety of learning style rather than traditional methods. This is because they are still practicing teacher-centered learning (Saleh \& Aziz, 2012). In this situation, the teacher is still a source of reference to get all kinds of help and information. Although this traditional teaching method has its own advantages such as saving teacher time and regulating class conditions, this technique is obviously lacking in the cooperative and sharing aspect of teaching and learning. Learning is a complex process that is not easily defined. Perhaps the most famous definition of learning is changing process in behavior or behavioral power that is the result of experience. This definition does not consider the various cognitive processes used in learning or personal, social, and emotional aspects of it (Entwistle \& Peterson, 2004). Based on, Klatter, Lodewijks, and Aarnouste's (2001) indicated that people have different ideas about learning, in which some point to learning consequences, some to learning necessities, and others to learning pur- 
poses. These various and adjoining dimensions of learning lead to the idea that learning is a multidimensional construct (Peterson, Brown, \& Irving, 2010). Attitude is a psychological state that is expressed through agreement or disagreement with a certain situation or value (Eagly \& Chaiken, 1993). Attitude has a psychological evaluation state that mediates between the different components that define the object of attitude and the categories of the peoples' reactions (Eagly \& Chaiken, 1993). People demonstrate their evaluations of situations through their reactions in various ways: identification with the situation, disagreeing with it, liking it or disliking it. The components of reaction are cognitive (beliefs), affective (feelings toward) and behavioral. Thus, if these are the components that constitute attitudes, then one can assume that there is a relationship between attitudes and behavior. Zimbardo (1992) highlights the interrelationship. Whereas, the potential benefits from the use of ICT for science learning have been reported in several research studies. One of these potential benefits is the encouragement of communication and collaboration in science activities. According to Gillespie (2006), new technologies can be used to enable students to collect science information and interact with resources, such as images and videos.

The usage of ICT is becoming more crucial in education as it enables the development of a more proactive teaching and learning environment (HamdzunHaron et al., 2018, Gabare et al., 2014, Daud \& Khalid, 2014). Together with the expansion of current era of technology, educators are encouraged to incorporate ICT into their teaching, as a substitute for traditional teaching methods (Kiflee \& Khalid, 2014). ICT is not only a tool for teaching and learning, but also acts as a driving force for an educator to play his or her role in education (Nur Qistina \& Hazman, 2006). For example, the application of ICT could expose students to various skills linked to their future needs, such as using Microsoft Word, email, and the internet for lifelong learning processes (Gabare et al., 2014; Khalid, 2014; Jones, 2011). Furthermore, the application of ICT can help educators to obtain resources from outside their networks, thus enabling them to transform the teaching and learning process.

\subsection{Study Aims and Objectives}

The purpose of this study was to determine the relationship of the student's attitude, interest, behavior, usage of ICT towards achievement in chemistry. Objectives of the study:

1) To examine the relationship between interest of students toward the achievement of chemistry.

2) To examine the relationship between attitude of students toward the achievement of chemistry.

3) To examine the relationship between behavior of students toward the achievement of chemistry.

4) To examine the relationship between usage of ICT toward the achievement of chemistry. 
5) To seek recommendations on how to improve students interest, attitudes, behavior and usage of ICT towards learning and achievement in chemistry.

\section{Methodology}

The target population of this study consists of Form 4 students at a school in Cheras Perdana, Selangor Malaysia. In this study, two form four classes are selected for conducting the research to find out the data for this study. The sample of this study consisted of 78 pupils from form four. Questionnaires are used as an instrument to obtain the necessary information for the construct of interest, behavior, attitude and usage of ICT. The questionnaire was adapted and modified from the previous study $(\mathrm{Ha}, 2000)$. The subject for the pilot study consisted of 30 pupils form 4 students at the school studied. The involved pupil is from the same population but not the actual survey respondent. The SPSS (Version 23) is use to analyze alpha Cronbach coefficient to test the consistency of the instrument. The results of the pilot study have shown that the value the reliability of each construct. Table 1 shows the reliability for each construct.

Questionnaire set was used to determine students' interest, behavior, attitude and the usage of ICT. In this study, the closed questionnaire was used because is very easy to operate and Likert Scale was selected to be used. Five point scale which is 1 to 5 , where the scale 5 is the positive value and the scale 1 is the negative value. The scale is selected because of its consistency and can be measured well. This method will use frequency and percentages to evaluate respondents' responses. A set of multiple choice question was used to determine the achievement of the chemistry subject. A series of suggestion, students need to rank the most influencing factor in enhancing learning.

\section{Research Findings}

\subsection{Achievement in Chemistry}

The study involved 78 Form Four students at a school in the Cheras Perdana, district of Selangor, comprising of three classes from science stream. From the data analysis, 3 students received grade A, (3.8\%), 3 students received grade A-, (3.8\%), 1 student received grade $\mathrm{B}+,(1.3 \%), 12$ students received grade $\mathrm{B},(15.4 \%)$ and 1 student received grade $\mathrm{B}-,(1.3 \%)$. These groups categorized as the highest achievement in chemistry $(25.6 \%)$. Whereas, 18 students received grade

Table 1. Reliability of each construct.

\begin{tabular}{cc}
\hline Construct & Alpha Cronbach \\
\hline Interest & 0.887 \\
Behavior & 0.848 \\
Attitude & 0.876 \\
Usage of ICT & 0.381 \\
\hline
\end{tabular}


$\mathrm{C}+$ to $\mathrm{C}-(23.1 \%)$ categorized as moderate achievement and 40 students received grade $\mathrm{D}, \mathrm{E}$ and $\mathrm{F}(51.2 \%)$ categorized as lowest. Table 2 shows achievement in chemistry.

The average percentages of students' choice for every item in each construct. The choice of students divides into three categories, label as highest, moderate and lower shows in Table 3.

Data shows 38 students (48.7\%), very positive in terms of interest, behavior, attitude and usage of ICT toward achievement, the other 23 students $(29.5 \%)$ and 17 students $(21.8 \%)$ which middle and lower category respectively. The interpretation for each construct toward achievement based on Table 4.

Correlation is an effect size and so we can verbally describe the strength of the correlation using the following guide for the absolute value of $0.01-0.25$ "very weak", value 0.26 - 0.50 "moderate", value 0.51 - 0.75 “strong”, and value 0.76 0.99 "very strong”. The calculation of Spearman's Rho correlation coefficient and subsequent significance testing of it requires the following data assumptions to hold interval or ratio level or ordinal, monotonically related. Note, unlike Pearson's correlation, there is no requirement of normality and hence it is a nonparametric statistic.

\subsection{Relationship between Interest and Achievement in Chemistry}

Inferential analysis is used to answer question and to test hypotheses that have been proposed. $\mathrm{Ho}^{1}$ There is no significant correlation of interest and achievement in chemistry. Table 5 shows the correlation between interest and achievement in chemistry. From the results, there was a significant positive correlation between interest and achievement in chemistry. The value of relationship is moderate $(\mathrm{r}=0.335)$ with $\mathrm{p}$ value $0.003(\mathrm{p}<0.05)$, a significant relationship, reject null hypothesis.

Table 2. Achievement in chemistry.

\begin{tabular}{cccc}
\hline Grading & Number of Students & Percentage (\%) & Category (\%) \\
\hline A & 3 & 3.8 & \\
A- & 3 & 3.8 & Highest \\
B+ & 1 & 1.3 & $(25.6 \%)$ \\
B & 12 & 15.4 & \\
B- & 1 & 1.3 & Moderate \\
C+ & 6 & 7.7 & $(23.1 \%)$ \\
C & 10 & 12.8 & \\
C- & 2 & 2.6 & Lowest \\
D & 9 & 11.5 & $(51.2 \%)$ \\
E & 9 & 11.5 & \\
F & 22 & 28.2 & \\
Total & 78 & 100 &
\end{tabular}


Table 3. Average percentage for every construct.

\begin{tabular}{ccccc}
\hline Construct & $\begin{array}{c}\text { Highest (\%) } \\
\text { (Scale 5 and 4) } \\
\text { Positive }\end{array}$ & $\begin{array}{c}\text { Moderate (\%) } \\
\text { Scale 3 } \\
\text { Middle }\end{array}$ & $\begin{array}{c}\text { Lowest (\%) } \\
\text { Scale 2 and 1 } \\
\text { Negative }\end{array}$ & $\begin{array}{c}\text { Total } \\
\text { (\%) }\end{array}$ \\
\hline Interest & $38(48.60 \%)$ & $24(31.15 \%)$ & $16(20.25 \%)$ & $78(100 \%)$ \\
Behavior & $33(42.17 \%)$ & $25(32.57 \%)$ & $20(25.26 \%)$ & $78(100 \%)$ \\
Attitude & $46(59.47 \%)$ & $21(27.15 \%)$ & $11(13.38 \%)$ & $78(100 \%)$ \\
Usage of ICT & $35(44.65 \%)$ & $20(26.02 \%)$ & $23(29.33 \%)$ & $78(100 \%)$ \\
& $38(48.7 \%)$ & $23(29.5 \%)$ & $17(21.8 \%)$ & \\
\hline
\end{tabular}

Table 4. Interpretation of the strength correlation results.

\begin{tabular}{cc}
\hline Correlation coefficient range & Strength of correlation \\
\hline 1.00 & Perfect correlation \\
0.76 to 0.99 & Very strong \\
0.51 to 0.75 & Strong \\
0.26 to 0.50 & Moderate \\
0.01 to 0.25 & Very weak \\
0.00 & No correlation \\
\hline
\end{tabular}

Table 5. Correlation coefficient between achievement in chemistry and interest.

\begin{tabular}{|c|c|c|c|c|}
\hline & & & Achievement & Interest \\
\hline \multirow{6}{*}{ Spearman's rho } & Achievement in Chemistry & Correlation Coefficient & 1.00 & $0.335^{* *}$ \\
\hline & & Sig. (2-tailed) & & 0.003 \\
\hline & & $\mathrm{N}$ & 78 & 78 \\
\hline & Interest & Correlation Coefficient & $0.335^{\star *}$ & \\
\hline & & Sig. (2-tailed) & 0.003 & \\
\hline & & $\mathrm{N}$ & 78 & 78 \\
\hline
\end{tabular}

\subsection{Relationship between Behavior and Achievement in Chemistry}

Inferential analysis is used to answer question and to test hypotheses that have been proposed. $\mathrm{Ho}^{2}$ There is no significant correlation of behavior and achievement in chemistry. Table 6 shows the correlation between behavior and achievement in chemistry. From the results, there was a significant positive correlation between behavior and achievement in chemistry. The value of relationship is moderate $(\mathrm{r}=0.323)$ with $\mathrm{p}$ value $0.004(\mathrm{p}<0.05)$, a significant relationship, reject null hypothesis.

\subsection{Relationship between Attitude and Achievement in Chemistry}

Inferential analysis is used to answer question and to test hypotheses that have 
been proposed. $\mathrm{Ho}^{3}$ There is no significant correlation of attitude and achievement in chemistry. Table 7 shows the correlation between attitude and achievement in chemistry. From the results, there was a significant positive correlation between attitude and achievement in chemistry. The value of relationship is moderate $(\mathrm{r}=0.271)$ with $\mathrm{p}$ value $0.016(\mathrm{p}<0.05)$, a significant relationship, reject null hypothesis.

\subsection{Relationship between Usage of ICT and Achievement in Chemistry}

Inferential analysis is used to answer question and to test hypotheses that have been proposed. $\mathrm{Ho}^{4}$ There is no significant correlation of usage of ICT and achievement in chemistry. Table 8 shows the correlation between usage of ICT and achievement in chemistry. From the results, there was a significant correlation (very weak) between usage of ICT and achievement in chemistry. The value of relationship is very weak $(r=0.025)$ with $p$ value $0.830(p>0.05)$, no significant relationship, accept null hypothesis.

\subsection{Recommendations on How to Improve Achievement in Chemistry}

Table 9 shows the recommendation from students' perspectives, in term of how to improve achievement in chemistry.

Table 6. Correlation coefficient between achievement in chemistry and behavior.

\begin{tabular}{|c|c|c|c|c|}
\hline & & & Achievement & Behavior \\
\hline \multirow{6}{*}{ Spearman's rho } & Achievement in Chemistry & Correlation Coefficient & 1.00 & $0.323^{\star \star}$ \\
\hline & \multirow{5}{*}{ Behavior } & Sig. (2-tailed) & & 0.004 \\
\hline & & $\mathrm{N}$ & 78 & 78 \\
\hline & & Correlation Coefficient & $0.323^{* *}$ & \\
\hline & & Sig. (2-tailed) & 0.004 & \\
\hline & & $\mathrm{N}$ & 78 & 78 \\
\hline
\end{tabular}

${ }^{* *}$ Correlation is significant at the 0.01 level (2-tailed).

Table 7. Correlation coefficient between achievement in chemistry and attitude.

\begin{tabular}{|c|c|c|c|c|}
\hline & & & Achievement & Attitude \\
\hline \multirow{6}{*}{ Spearman's rho } & Achievement in Chemistry & Correlation Coefficient & 1.00 & $0.271^{\star *}$ \\
\hline & \multirow{5}{*}{ Attitude } & Sig. (2-tailed) & & 0.016 \\
\hline & & $\mathrm{N}$ & 78 & 78 \\
\hline & & Correlation Coefficient & $0.271^{\star *}$ & \\
\hline & & Sig. (2-tailed) & 0.016 & \\
\hline & & $\mathrm{N}$ & 78 & 78 \\
\hline
\end{tabular}

${ }^{*}$ Correlation is significant at the 0.01 level (2-tailed). 
Md. Y. Daud et al.

Table 8. Correlation coefficient between achievement in chemistry and usage of ICT.

\begin{tabular}{lcccc}
\hline & & \multicolumn{2}{c}{ Achievement } & Usage of ICT \\
\hline & Achievement in Chemistry & Correlation Coefficient & 1.00 & $0.025^{* *}$ \\
& & Sig. (2-tailed) & & 0.830 \\
Spearman's rho & $\mathrm{N}$ & 78 & 78 \\
& \multirow{2}{*}{ Usage of ICT } & Correlation Coefficient & $0.025^{* *}$ & \\
& & Sig. (2-tailed) & 0.830 & \\
& & $\mathrm{~N}$ & 78 & 78 \\
\hline
\end{tabular}

${ }^{* *}$ Correlation is significant at the 0.01 level (2-tailed).

Table 9. Students suggestion.

\begin{tabular}{cc}
\hline Students suggestions & Percentages (\%) \\
\hline I will change my attitude towards chemistry subject & 35 \\
I need a senior teacher to teach me & 22 \\
I need to work in group to inculcate interest & 18 \\
I need teacher to enhance teaching style & 15 \\
Improve facilities related to ICT & 10 \\
\hline
\end{tabular}

\section{Discussions}

This section discusses the results of research findings. The finding for each question and the hypotheses of the study are based on the relationship between interest, behavior, attitude, usage of ICT toward achievement in chemistry. This study demonstrated a significant relationship between interest, behavior, attitude, usage of ICT and their academic achievement in chemistry as measured. The value of relationship significantly predicted their academic achievement significant correlate to interest, behavior and Attitude. But the output shows a weak correlation of the usage of ICT toward achievement. From the results, it can be concluded that students that are highly self-directed can depend on themselves in learning and would have greater academic achievement. In order to incorporate suitable teaching strategies to match the student's needs, schools should not only diagnose their students' (especially new students) ability and the factors that are associated with academic achievement in chemistry. In term of technologies, most of the school quite difficult to integrate ICT in classroom because of lacking of facilities and time constrain. In the other point of view, most of the students very patient in learning. The students' suggestions can also act as an intrinsic factor to help students' success; hence, it would be useful to the teacher or school administrate in supporting students at their appropriate levels.

The findings show a significant relationship in interest, behavior and attitude toward achievement. This was because despite the students being of different academic background, they have the same spirit, culture, language, local area to move forward. By the way, the study has found no significant relationship be- 
tween usage of ICT and achievement. It was suggested that the facilities to accommodate integrating ICT in classroom still at early phases. The insignificance of the relationship may be due to the lacking of the facilities especially networking and internet access. The knowledge can be utilized to prepare suitable programs to support these different levels, which may progress the school academic achievement and prepare the students to enter university. The results of this study would add to the growing body of researches on factors predicting academic success in chemistry among school students.

\section{Conclusion}

The study found out that most students had a positive attitude, interest, behavior towards achievement in chemistry, they perceived achievement which can be improved by changing the attitude and confidence, everything as doable, learnable and important yet, this translate to good grades. The findings also show that perceptions and beliefs, perceived learning abilities and competencies and previous performances of students in chemistry affected their level of motivation leading to low outcomes. The study recommends the use of varied instructional strategies by the teachers, which promote discovery and elicit learner interest. The students should be encouraged to apply the taught knowledge and skills through feedback and assignments. Therefore, there is a need to offer and build on experiences and opportunities that inspire the students to engage fully in the material fact and acquire knowledge and skills that would enable them to excel in the chemistry.

\section{Acknowledgements}

This work was supported by UKM [Grant PP-FPEND-2019] and [Grant GG-2019-018].

\section{Conflicts of Interest}

The authors declare no conflicts of interest regarding the publication of this paper.

\section{References}

Daud, M. Y., \& Khalid, F. (2014). Nurturing the 21st Century Skills among Undergraduate Students through the Application and Development of Weblog. International Education Studies, 7, 123-129. https://doi.org/10.5539/ies.v7n13p123

Eagly, A., \& Chaiken, S. (1993). The Psychology of Attitudes. New York: Harcourt Brace Jovanovich College Publishers.

Entwistle, N. J., \& Peterson, E. R. (2004). Conceptions of Learning and Knowledge in Higher Education: Relationships with Study Behaviour and Influences of Learning Environments. International Journal of Educational Research, 41, 407-428. https://doi.org/10.1016/j.ijer.2005.08.009

Gabare, C., Gabarre, S., Din, R., Shah, P. M., \& Karim, A. A. (2014). iPads in the Foreign Language Classroom: A Learner's Perspective. The Southeast Asian Journal of English 
Language Studies, 20, 115-128.

Gillespie, H. (2006). Unlocking Learning and Teaching with ICT: Identifying and Overcoming Barriers. London: David Fulton.

Ha Pick, Y. (2000). Hubungan Antara SikapPelajardenganPencapainTerhadap Mata Pelajaran Kimia. LatihanIlmiah. Bangi: UKM. (Unpublish)

Haron, H., Hanafi, J., Ahmad, Z., Zainal, K., Mamat, M., \& Yusof, dan A. S. (2018). The Reasons Concerning Teachers' Attitude toward Computer in Education at Primary Level. International Journal of Civil Engineering and Technology, 9, 326-335.

Hashim, M. N., Embi, M. A., \& Hashim, H. (2019). A Single Case Study. The Perception and Teaching Practices of a Malaysian Primary School English Teacher Regarding Student-Teacher Relationship. In Proceedings of International Conference on Humanities, Education and Society (pp. 167-179). Kuala Lumpur: Malaysia

Jones, P. H. (2011). The Impact of Digital Technologies on Human Wellbeing. In D. Sutch (Ed.), Evidence from the Sciences of Mind and Brain. United Kingdom: Nominet Trust.

Khalid, F. (2014). Students' Views on the Use of e-Portfolio and Support Given to Promote Their Computer Learning for Educational Purposes. Recent Advance in Telecommunications, Informatics and Educational Technologies, 1, 54-59.

Kiflee, C. S., \& Khalid, F. (2014). Keberkesanan Kaedah Multimedia dalam Pengajarandan Pembelajaran Terhadap Pelajar-Pintar. In F. Khalid (Ed.), International Seminar on Global Education II: Education Transformation towards a Developed Nation (pp. 135-159). Bangi: Fakulti Pendidikan, UKM.

Klatter, E. B., Lodewijks, H. G. L. C., \& Aarnouste, C. A. J. (2001). Learning Conceptions of Young Students in the Final Year of Primary Education. Learning and Instruction, 11, 485-516. https://doi.org/10.1016/S0959-4752(01)00002-0

Ministry of Education (2013). Malaysia Education Blueprint (2013-2025): Preschool to Post-Secondary Education. Putrajaya: Ministry of Education

Nur, Q., \& Hazman, A. (2006). Penggunaan Teknologi Maklumat dan Komunikasi (ICT) dalam Kalangan Guru-Guru Sekolah Kebangsaan. Johor Bahru: Universiti Teknologi Malaysia.

Peterson, E. R., Brown, G. T. L., \& Irving, S. E. (2010). Secondary School Students' Conceptions of Learning and Their Relationship to Achievement. Learning and Individual Differences, 20, 167-176. https://doi.org/10.1016/j.lindif.2009.12.004

Saleh, S., \& Aziz, A. (2012). Teaching Practices among Secondary School Teacher in Malaysia. International Proceedings of Economic Development and Research, 47.

Simin, G., \& Ibrahim, M. S. (2015). Effectiveness of ICT Integration in Malaysia Schools: A Quantitative Analysis. International Research Journal for Quality in Education, 2, $1-12$.

Zimbardo, P. (1992). The Psychology of Attitude Change and Social Influence. New York: McGraw Hill. 